\title{
Ecological diversification in habitat use by subtidal triplefin fishes (Tripterygiidae)
}

\author{
Maren Wellenreuther ${ }^{1, *}$, Paul T. Barrett ${ }^{2}$, Kendall D. Clements ${ }^{1}$ \\ ${ }^{1}$ School of Biological Sciences, and ${ }^{2}$ Department of Management and Employment Relations, University of Auckland, \\ Private Bag 92019, Auckland, New Zealand
}

\begin{abstract}
Recent work has shown that habitat specialisation can lead to diversification in lacustrine and marine fish species. Here we investigate specialisation in the New Zealand triplefin fish fauna (Tripterygiidae), which has the greatest diversity and disparity of triplefin species in the world with 26 endemic species. Most species are sympatric throughout coastal New Zealand, showing no obvious latitudinal trends in abundance. We sampled habitat use quantitatively, and microposition qualitatively, in 17 triplefin species at 151 sites representing a geographic range from $35^{\circ} 50^{\prime} \mathrm{S}$ to $46^{\circ} 70^{\prime} \mathrm{S}$. A novel Euclidean-distance non-metric multidimensional scaling (MDS) technique was used to display the quantitative habitat variables (depth, fetch, rock, cobble, gravel, sand, mud, macroalgae, and coralline and turfing algae) of each species. For each species, the positions of these variables were compared to those of all species using Procrustes configural matrix comparison methodology, which resulted in a final 3D spatial representation of species using non-metric MDS. Our results demonstrate that triplefin species have diversified considerably in habitat and microposition use, resulting in species occupying different patches in the same general location. Strong habitat partitioning was shown by 3 distinct clusters of species along a gradient of depth and exposure. Some species showed an even finer sub-partitioning by using different substratum types, in particular rock and mud. Correspondence Analysis of microposition data showed that 5 species differed from all other species, further partitioning habitat use. Thus, our results suggest that habitat use has been important in the diversification of New Zealand triplefin fishes.
\end{abstract}

KEY WORDS: Ecological diversification • Habitat preference · Sympatry • Tripterygiidae • Multidimensional scaling $\cdot$ Reef fish $\cdot$ Ecological divergence $\cdot$ Fish assemblages

\section{INTRODUCTION}

The role of resource partitioning in the coexistence of ecologically similar species and in adaptive diversification has been the subject of much debate. Specialisation resulting from ecological diversification is thought to be a key factor in the partitioning of resources and the coexistence of species, and recent research has focused on the evolutionary and ecological processes responsible for generating and maintaining this diversity (Malavasi et al. 2005, Rocha et al. 2005).

Diversification in the use of ecological resources has been widely documented in coral reef fishes, resulting in numerous descriptions of distinct patterns of habitat utilization among closely related species (Bouchon-
Navaro et al. 2005). Examples include coral reef fish families such as blennies (Wilson 2001), damselfishes (Bay et al. 2001), parrotfishes (Gust et al. 2001), and gobies (Munday \& Jones 1997). While resource use has been extensively studied within coral reef fish assemblages, the range of habitats occupied and the use of particular habitat features by temperate reef fishes are generally poorly known. Like coral reefs, temperate environments are characterised by great spatial heterogeneity in substrate composition and complexity on a range of spatial scales (Syms 1995). Temperate fish assemblages vary along gradients of topographic complexity (Connell \& Jones 1991, Schofield 2003), substrate type (Nemeth 1998), exposure (Thorman 1986), the degree of substratum relief (La Mesa \& Vac- 
chi 2005) and microhabitat structure (Ormond et al. 1996). However, not all temperate fish species respond to every type of habitat variable, and different species may partition some environmental variables and not others.

New Zealand triplefin fishes (Family Tripterygiidae) are an ideal model system to study ecological diversification of habitat use, as all species occupy small territories after settlement, are highly philopatric, and mate within their territory (Clements 2003). The high site fidelity is further exemplified by the ability of some species to home, even if displaced over several $100 \mathrm{~m}$ (Thompson 1983, Fisher 1998). In addition, there is strong evidence to suggest that triplefins exert speciesspecific habitat choice at settlement (M. Wellenreuther \& K. D. Clements unpubl.). The New Zealand triplefin fauna has the greatest diversity and disparity of triplefin species in the world with 26 endemic species in 14 genera (Hickey \& Clements 2005). Triplefin distributions in New Zealand show no obvious latitudinal trends in abundance (Clements 2003), which is unusual as most coastal New Zealand fish species are either distinctly northern or southern in distribution (Francis 2001).

Although common in the diversification of other fish radiations, trophic resource partitioning ( $\mathrm{Lu} \&$ Bernatchez 1999) and sexual selection on male body coloration (Allender et al. 2003) are unlikely to have been important in the diversification of the New Zealand triplefin fauna. Most New Zealand triplefin species appear to be trophic generalists, with the 2 notable exceptions of Obliquichthys maryannae and Blennodon dorsale (Feary 2001). Males of most species assume a dark spawning coloration during the reproductive season (Francis 2001, Clements 2003), and thus the pattern of interspecific differences in colour patterns is the opposite of that predicted under sexual selection (Seehausen et al. 1997). Previous work has shown that New Zealand triplefins have diversified into a variety of habitats, ranging from estuaries and shallow rockpools to deep reefs (Clements 2003). Previous studies are restricted to species in rocky reef habitats in northeastern New Zealand. Furthermore, no studies to date have assessed habitat use quantitatively, and as a result lack detailed interspecific comparisons.

This study investigates the role of habitat specialisation in ecological diversification of the New Zealand triplefin assemblage by recording habitat use data for 17 triplefin species. Study locations were selected all around New Zealand from $35^{\circ} 50^{\prime} \mathrm{S}$ to $46^{\circ} 70^{\prime} \mathrm{S}$ to encompass the latitudinal and environmental range of most triplefin species (Fricke 1994). The main objective was to investigate whether New Zealand triplefin species show interspecific divergence in habitat and microposition use. It was predicted that if ecological adaptation to different habitats has contributed to the diversification of the New Zealand triplefin assemblage species should display considerable interspecific differences in habitat use. Conversely, if species show little or no differentiation in habitat use then adaptation to different habitats has not played a key role in diversification.

\section{MATERIALS AND METHODS}

Selection of species. A sampling method was designed to census the majority of triplefin species that occur in coastal waters around New Zealand, namely Apopterygion oculus, Bellapiscis lesleyae, Cryptichthys jojettae, Forsterygion flavonigrum, F. lapillum, F. malcolmi, F. varium, Grahamina capito, G. gymnota, G. nigripenne, Karalepis stewarti, Notoclinops caerulepunctus, N. segmentatus, N. yaldwyni, Obliquichthys maryannae, Ruanoho decemdigitatus and $R$. whero. The highly cryptic species Gilloblennius tripennis, Notoclinus compressus and Notoclinus fenestratus, which are found amongst seaweed (Clements 2003), were not censused. Other species not sampled included those that inhabited intertidal (i.e. B. medius), highly exposed (i.e. Blennodon dorsale and Gilloblennius abditus), and deep-water habitats (i.e. Matanui bathytaton and M. profundum) (Clements 2003).

Selection of locations and sites. Triplefin habitat use was documented from 2002 to 2005 at 7 locations (Three Kings Islands, Coromandel Peninsula, Hauraki Gulf, Napier, Wellington, Fiordland and Stewart Island) around New Zealand (Fig. 1) using underwater visual censusing (UVC). Locations were selected to cover the latitudinal range and environmental gradients of the habitats used by the study triplefin species (Fricke 1994, Francis 1996). The Three Kings Islands $\left(35^{\circ} 50^{\prime} \mathrm{S}, 172^{\circ} 10^{\prime} \mathrm{E}\right)$ are situated approximately $60 \mathrm{~km}$ northwest of the northernmost tip of New Zealand, and represent a highly exposed, isolated location that is the northern distributional limit for coastal triplefin species (Brook 2003). Sampling at the Three Kings Islands, in particular at depths of less than $5 \mathrm{~m}$, was constrained by the high exposure of some sites. The northern tip of the eastern coast of the Coromandel Peninsula ( $\left.36^{\circ} 29^{\prime} \mathrm{S}, 175^{\circ} 19^{\prime} \mathrm{E}\right)$ and Hauraki Gulf and associated offshore islands $\left(36^{\circ} 36^{\prime} \mathrm{S}, 174^{\circ} 50^{\prime} \mathrm{E}\right)$ were selected to represent coastal and offshore island sites in an intermediate position between the most northern and southern locations of the North Island. The Napier area $\left(39^{\circ} 29^{\prime} \mathrm{S}, 176^{\circ} 55^{\prime} \mathrm{E}\right)$ is situated in a large semicircular bay on the east coast of the North Island, and is characterised by relatively sheltered, shallow and silty shores (Chiswell 2002). To census exposed sites in the Napier region several boat trips to the highly exposed Pania Reef $\left(39^{\circ} 26^{\prime} \mathrm{S}, 176^{\circ} 58^{\prime} \mathrm{E}\right)$ were under- 

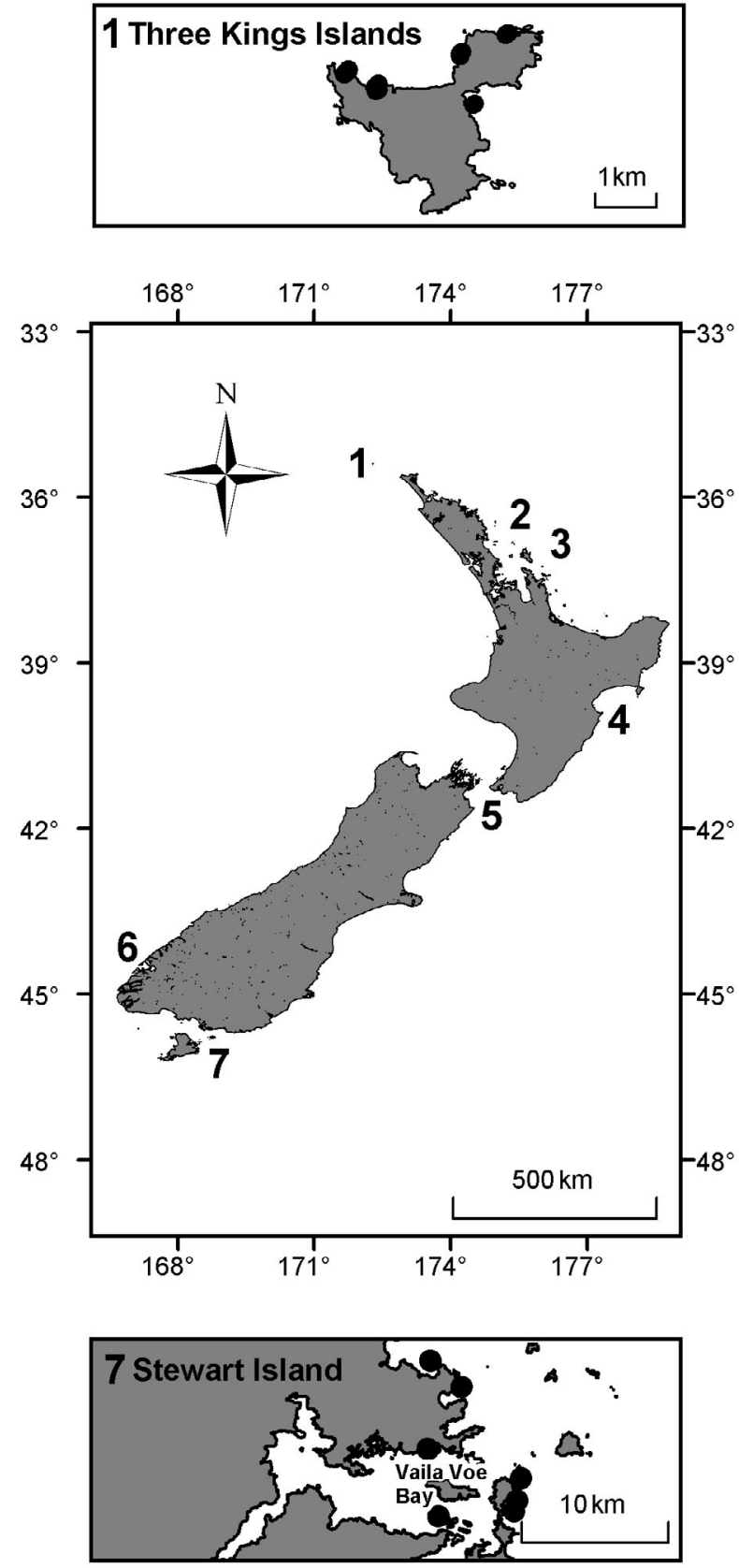

Fig. 1. Sampling locations around New Zealand.
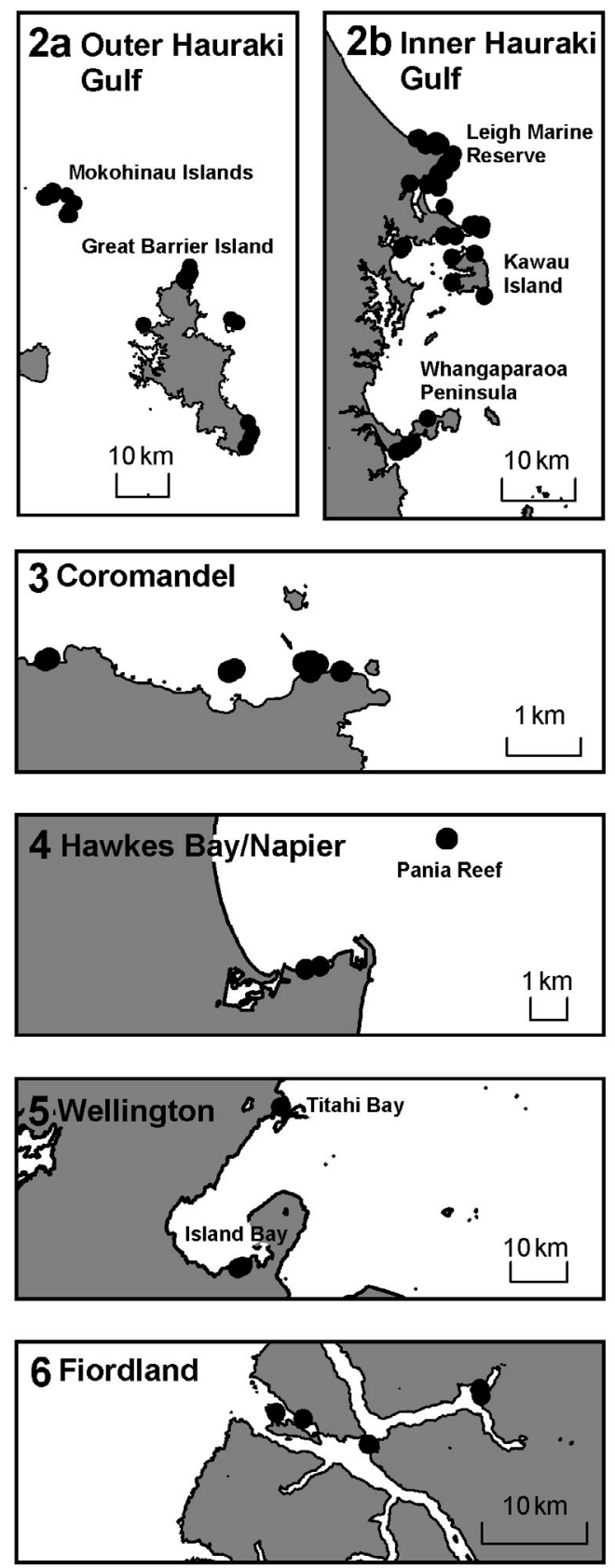

Position of sampling sites taken. Wellington $\left(41^{\circ} 16^{\prime} \mathrm{S}, 174^{\circ} 51^{\prime} \mathrm{E}\right)$ lies at the southern end of the North Island, and represents an intermediate latitudinal location. To cover a wide exposure gradient in the Wellington area, sites were selected at Titahi Bay $\left(41^{\circ} 10^{\prime} \mathrm{S}, 174^{\circ} 53^{\prime} \mathrm{E}\right)$ and Island Bay $\left(41^{\circ} 33^{\prime} \mathrm{S}, 174^{\circ} 78^{\prime} \mathrm{E}\right)$. Fiordland was chosen as it represents a unique environment of deep fjords located over a $200 \mathrm{~km}$ stretch of the southwestern coast of South Island. Heavy rainfall in the Fiordland region causes a thick freshwater layer that is stained by organic matter (Wing 2003), and this can cause a salinity stratification and extremely low light levels even at shallow depths. The southernmost location sampled was Stewart Island $\left(46^{\circ} 60^{\prime} \mathrm{S}, 168^{\circ} 20^{\prime} \mathrm{E}\right)$, which is New Zealand's third largest, and southernmost large island, separated from the mainland by the shallow Foveaux Strait (Heath 1985).

Within each location $4 \times 4$ UVC were conducted at randomly selected sites with the aim of sampling as much of the exposure gradient as was practically pos- 
sible. While the sampling sites attempted to be representative of the shallow subtidal environments occupied by triplefin species $(<36 \mathrm{~m})$, some highly exposed sites could not be sampled (e.g. some sites at the Three Kings Islands). This limitation meant that species whose range extends into highly exposed habitats (i.e. Bellapiscis lesleyae) were only sampled at the lower exposure range.

Collection of data. Prior to sampling a location fix was taken for each site using handheld Garmin ${ }^{\circledR} 12$ global positioning system (GPS) (accuracy $\pm 15 \mathrm{~m}$ ). From this GPS information a physically derived exposure index could be calculated based on the total sum of the fetch (maximum radial distance $300 \mathrm{~km}$ ). Fetch is the distance of open water over which waves can be generated by winds, and is thus an approximation of wave exposure. Fetch calculations were performed with the program Fetch Effect Analysis (available from the author: cr_pickard@hotmail.com), which measures fetch distance for each $20^{\circ}$ sector on a compass rose from a given point (GIS fix) (Thomas 1986).

At least 3 sampling areas $(4 \times 4 \mathrm{~m})$ were laid out on each site. The first sampling area at each site was done at the deepest depth that could safely be sampled (maximum depth dived $36 \mathrm{~m}$ ), and the 2 subsequent sampling areas at approximately 66 and $33 \%$ of the deepest depth. Any additional sampling areas were conducted in intermediate depths. This design was employed to allow sampling flexibility throughout sampling locations. A minimum distance of approximately $50 \mathrm{~m}$ between sampling areas was maintained to avoid dependent samples (Andrew \& Mapstone 1987). The centre line of each sampling area was marked with a leaded line, and a steel quadrat used to outline each $1 \mathrm{~m}^{2}$ within sampling areas. In this study, all UVC were done by the same diver and consisted of a close, rigorous and systematic searching pattern, spending at least $1 \mathrm{~min}$ on each quadrat, with all interstices and overhangs examined to ensure a complete census. The spatial scale at which small fishes such as triplefins perceive differences in habitat features should be small and comparable with the range of movements exhibited (La Mesa \& Vacchi 2005). For this reason habitat use was recorded for each $1 \mathrm{~m}^{2}$ within sampling areas. For each $1 \mathrm{~m}^{2}$ quadrat depth was recorded and 7 habitat variables estimated visually as percent cover of the substratum: rock (rocks $>7 \mathrm{~cm}$ ), cobbles (rocks $<7 \mathrm{~cm}$ ), gravel (rocks $<4 \mathrm{~cm}$ ), sand, mud, macroalgae, and coralline and turfing algae. While the first 5 variables always sum to $100 \%$, algal coverage could range from 0 to $100 \%$. The fish within each quadrat were identified, and the microposition of each fish (Table 1) on which it was first encountered recorded. Microposition use provides evidence of the fine scale habitat use of each species, and thus indicates interspecific overlap on a finer scale than
Table 1. Triplefin microposition abbreviations modified from Syms (1995) and Feary \& Clements (2006)

\begin{tabular}{|lc|}
\hline Microposition & Abbreviations \\
\hline Side and top of rock & STB \\
Under rock or in crack on horizontal/ & UCS \\
vertical slope & \\
Under an overhang & UOV \\
Upside down on overhang & ROV \\
On top of cobbles & TCO \\
On sand or mud, without cover & SM \\
Free-swimming & FRE \\
On algae & ALG \\
\hline
\end{tabular}

the habitat analysis. For example, species can occupy the same $1 \times 1 \mathrm{~m}$ patch, but one species can occupy the top and side of the rocks (STB) while the other can occupy the horizontal and vertical cracks of the rocks (UCS).

The use of UVC as a sampling method for triplefins was criticised by Willis (2001). Willis compared ichthyocide and UVC counts and concluded that density and diversity estimates were considerably lower in the UVC method. This conclusion is questionable for several reasons. First, Willis failed to restrict the census target to triplefin species, but instead attempted to census a wide range of pelagic and demersal species at the same time. Second, Willis conducted all censuses $0.5 \mathrm{~m}$ above the substratum, and thus did not search the substratum accurately. Third, the area that was effectively searched for the ichthyocide counts was larger than the area censused for the UVC method, since fish affected by the ichthyocide were collected outside the UVC census area. Willis (2001) thus fails to provide a valid argument against the use of UVC for New Zealand triplefin species. Furthermore, several studies have used UVC counts to census triplefin species and achieved robust results (e.g. Connell \& Jones 1991, Syms 1995, Feary \& Clements 2006).

Interspecific overlap in habitat use. The overarching goal of this part was to examine overlap in habitat use by New Zealand triplefin species based on habitat similarity. A survey of the literature revealed no common procedures to analyse and summarise multidimensional, quantitative habitat data without losing distance relationships between habitat variables. Therefore, a method was developed that uses doublescaled Euclidean (DSE) distances as a dissimilarity measure between habitat variables for a species (Barrett 2005a). The double-scaling refers to the procedures used to transform a conventional Euclidean distance into a universal 0 (no distance between objects) to 1 (maximum possible discrepancy) range using a strictly linear methodology. Essentially, squared discrepancies between 2 objects or cases are standard- 
ized by the respective maximum possible squared discrepancy for each paired comparison, this distance is again re-standardized by the square root of the number of components forming the Euclidean distance. The 'components' are the number of individuals per species observed using 2 variables for which the DSE estimate is being computed. This double transformation avoids problems with non-linear data standardization-normalisation procedures by using only linear scaling procedures, making the DSE coefficients comparable between themselves and between studies.

Initially, for each species, every variable was compared to every other variable, with the comparison indexed using DSE distances to represent the usage distance between each variable. The habitat data consisted of depth, exposure (fetch) and 7 substratum variables (rock, cobble, gravel, sand and mud, macroalgae and coralline and turfing algae), taken from 7 locations around New Zealand. A Statistica Visual Basic program Agreement Matrix Constructor (Barrett 2005b) was written for this purpose. Where an individual failed to be observed using both habitat variables (joint absence), then that individual was excluded from the calculation for that particular variable pair (akin to the logic of a Jaccard measure of an agreement). The rationale here is that if an individual failed to be observed using 2 habitat variables then actually no information exists about the habitat use by that individual.

To obtain an overall species similarity matrix the DSE distances between variables for each species were submitted to a non-metric Guttman-Lingoes MDS procedure in Statistica to derive habitat variable usage maps for each species in 2D space. Two dimensional MDS plots were chosen because the stress values for each species were less than 0.2 in each case (Clarke \& Warwick 2000). In order to generate a species similarity map, each 2D MDS solution for each species was compared to every other species solution using the procrustes orthogonal matrix comparison routine ORTHOSIM2 (Barrett 2005c). The program works by configurally rotating a comparison matrix of MDS coordinates against a target matrix so as to minimize the sum of squared deviations between the comparison matrix and target matrix coordinate values. When submitting MDS coordinate dimensions for comparison, both matrices are initially centred, row-normalized (akin to a procrustes' transformation, which expresses each matrix in a normalized unit metric space which preserves the distance relations), and reflected (arithmetic sign reversal) where necessary. The reason for these specific transformations is that MDS solutions are arbitrary in terms of their location, scale, and orientation of variables in geometric space. It is the distance relations between variables that are critical in the MDS procedure, and these can be preserved while allowing the origin, scale, and coordinate reflection of the solutions to vary. Thus, when comparing the coordinates from MDS solutions, the coordinates must be expressed within a common geometric space with common origin and coordinate signs. The similarity of the 2 rotated MDS habitat variable coordinate matrices was expressed as a DSE similarity (DSE-S) coefficient (simply 1 - DSE Distance), where 0 now equals maximum possible discrepancy and 1 equals absolute identity. The DSE-S values of each species comparison were entered into a species comparison similarity matrix and visualised using the same MDS routine in Statistica, v7. D-hat raw stress was used to evaluate how well the final MDS configuration reproduced the estimated similarities. The appropriate number of MDS dimensions were chosen according to the stress value threshold of 0.2 (Clarke \& Warwick 2000), above which configurations are considered to be poor representations of the data.

A prerequisite to run these coordinate comparisons is that the same variables are compared in the target and the comparison MDS plots, and that the coordinates are orthogonal. As a consequence, species without observations for some of the habitat variables could only be compared to all other species on the basis of the mutual habitat subsets. The species with missing observations for some habitat variables were Grahamina nigripenne (missing: gravel and macroalgae), Grahamina gymnota (missing: sand and coralline and turfing algae), Bellapiscis lesleyae (missing: sand and mud) and Apopterygion oculus (missing: cobble, gravel and coralline and turfing algae).

Interspecific overlap in microposition use. Microposition use of all species was analysed and graphically summarised via the correspondence analysis routine in Statistica (v7). Correspondence Analysis uses chisquare transformation, meaning the proportions of species are considered rather than their absolute abundances. Correspondence Analysis is an exploratory technique designed to analyse some measure of correspondence between the rows (species) and columns (microposition categories). The resulting graph provides information about which species are similar in terms of microposition use, with similar species being closely placed in multi-dimensional space.

\section{RESULTS}

\section{Interspecific overlap in habitat use}

In total, 15488 individual fish observations were recorded at 7 locations around New Zealand (Table 2). All species showed strong differentiation in depth and exposure (Fig. 2). Three clusters of species were appar- 
Table 2. Number of observations of each species at each location. Observations were pooled at species level (Total) and analysed globally. Locations included: Three Kings (3K), Hauraki Gulf (H), Coromandel (C), Napier (N), Wellington (W), Fiordland (F) and Stewart Island (S)

\begin{tabular}{|lcccccccc|}
\hline Species & Total & $3 \mathrm{~K}$ & $\mathrm{H}$ & $\mathrm{C}$ & $\mathrm{N}$ & $\mathrm{W}$ & $\mathrm{F}$ & $\mathrm{S}$ \\
\hline Apopterygion oculus & 37 & 0 & 0 & 0 & 0 & 0 & 0 & 37 \\
Bellapiscis lesleyae & 176 & 0 & 99 & 0 & 0 & 18 & 59 & 0 \\
Cryptichthys jojettae & 234 & 129 & 66 & 5 & 0 & 0 & 0 & 34 \\
Forsterygion flavonigrum & 941 & 3 & 247 & 1 & 1 & 0 & 532 & 157 \\
Forsterygion lapillum & 3803 & 0 & 2865 & 148 & 124 & 351 & 239 & 76 \\
Forsterygion malcolmi & 384 & 7 & 80 & 67 & 84 & 1 & 99 & 46 \\
Forsterygion varium & 2167 & 77 & 830 & 186 & 201 & 218 & 178 & 477 \\
Grahamina capito & 879 & 0 & 178 & 0 & 1 & 28 & 671 & 1 \\
Grahamina gymnota & 33 & 0 & 0 & 0 & 33 & 0 & 0 & 0 \\
Grahamina nigripenne & 337 & 0 & 152 & 0 & 0 & 0 & 185 & 0 \\
Karalepis stewarti & 75 & 18 & 35 & 3 & 0 & 6 & 1 & 12 \\
Notoclinops caerulepunctus & 245 & 0 & 158 & 0 & 0 & 0 & 87 & 0 \\
Notoclinops segmentatus & 2336 & 0 & 1894 & 26 & 15 & 69 & 103 & 229 \\
Notoclinops yaldwyni & 465 & 101 & 334 & 12 & 18 & 0 & 0 & 0 \\
Obliquichthys maryannae & 1495 & 46 & 596 & 70 & 0 & 16 & 445 & 322 \\
Ruanoho decemdigitatus & 232 & 0 & 79 & 0 & 101 & 52 & 0 & 0 \\
Ruanoho whero & 1649 & 92 & 1371 & 70 & 25 & 10 & 9 & 72 \\
\hline
\end{tabular}

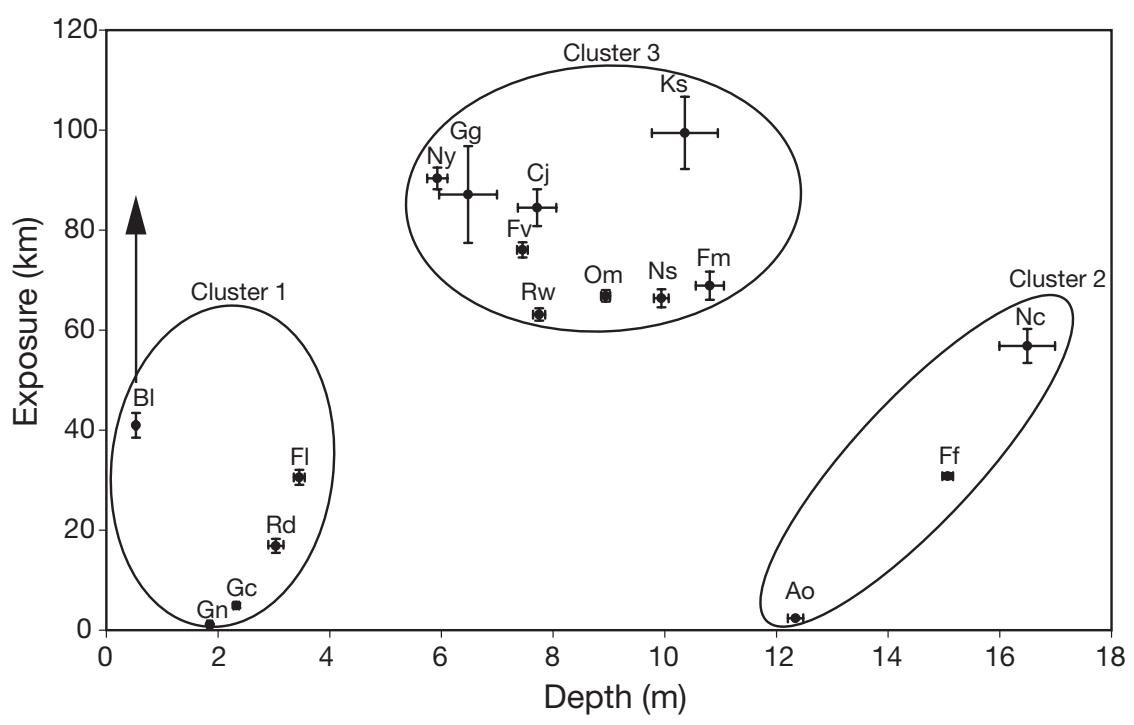

Fig. 2. Mean use of depth and exposure (fetch) by triplefin species. The $x$ - and $y$ error bars: SE. The arrow indicates that the exposure range of Bellapiscis lesleyae is likely to be higher. Species names are abbreviated by the first letter of the genus followed by the first letter of the species name. See Table 2 for a list of species names

ent. Cluster 1 consisted of species characterised by sheltered and extremely shallow habitats, namely $R u$ anoho decemdigitatus, Forsterygion lapillum, Grahamina capito and G. nigripenne (Fig. 2). The placement of Bellapiscis lesleyae in this cluster is somewhat problematical, as the exposure estimates obtained in this study underestimate the true range experienced by this species (see 'Materials and methods'). This species occurs both in the intertidal and subtidal, and is most of- ten found in the surge zone (Paulin \& Roberts 1992). Consequently, the habitat of this species could only be surveyed in relatively sheltered sites (i.e. Hauraki Gulf and Fiordland). It was impossible to census $B$. lesleyae at highly exposed sites (i.e. Three King Islands and Stewart Island), despite the species being abundant at these locations. The arrow in Fig. 2 indicates that the mean exposure of this species is higher than suggested by the data in this study. Cluster 2 is characterised by species that occupy deep and relatively sheltered habitats, and included Apopterygion oculus, Notoclinops caerulepunctus and F. flavonigrum (Fig. 2). The third and largest cluster (Cluster 3) included all the remaining species, which commonly use habitats of medium depths and moderate to high exposure (Fig. 2).

There was also a degree of interspecific difference in the use of the substratum types (Fig. 3), but overlap between species was much more pronounced relative to the strong differentiation shown in depth and exposure. Rock was the most frequently used habitat component by all species with the exception of Apopterygion oculus, Grahamina nigripenne and G. capito (Fig. 3). Specifically, $A$. oculus was the only species that was never found near rock, but instead was exclusively found in a habitat characterised by a mixture of sand and mud with red drift algae. However, the results for $A$. oculus have to be viewed with caution as this species was only recorded from one location (Stewart Island). G. nigripenne and G. capito were also commonly found on muddy substrates, though were never far from rocky shelter (Fig. 3). The 2 remaining variables, gravel and cobble, were used to a low degree by all species $(<20 \%)$

(Fig. 3). Some species occupied habitats that contained macroalgae and/or coralline and turfing algae. For example, coralline and turfing algae played a dominant part in the habitat of Cryptichthys jojettae, and also formed a consistent part of the habitats of all 3 Notoclinops species, Karalepis stewarti and Ruanoho whero (> 30\%) (Fig. 3). Macroalgae were found to be associated to a moderately high degree $(<30 \%)$ with the habitats of all species except for Bellapiscis lesleyae and $G$. nigripenne. 


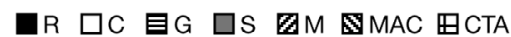

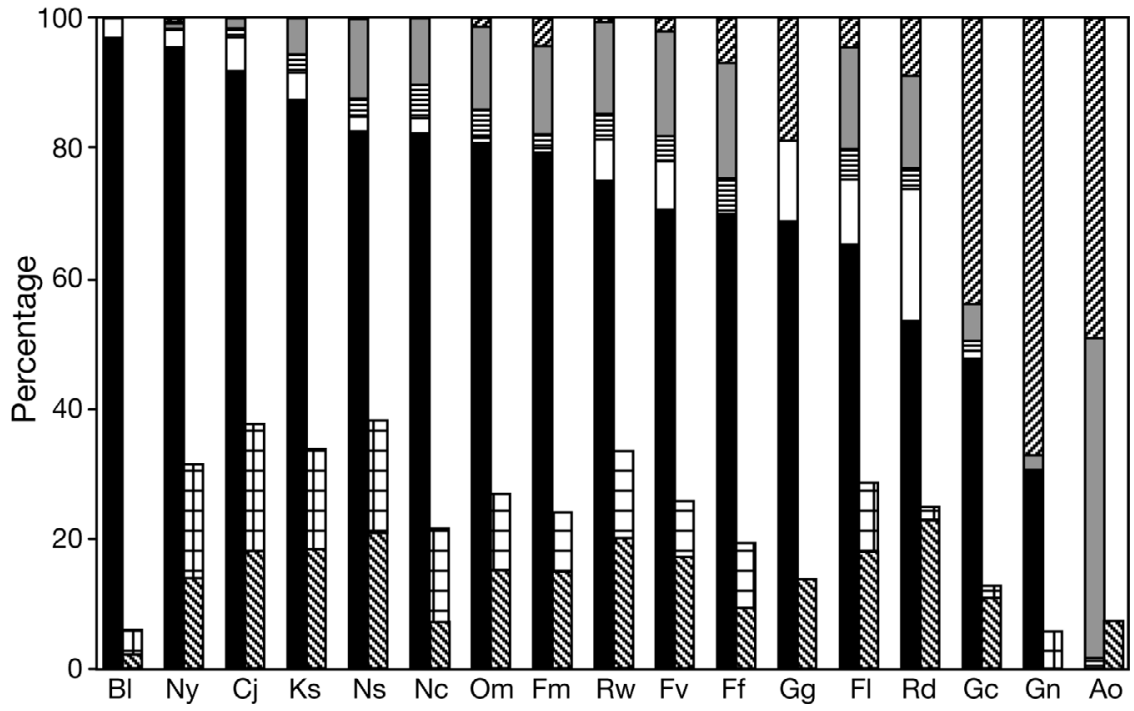

Fig. 3. Mean percentage use of substratum variables. Substratum types (rock, cobble, gravel, sand and mud) always add up to $100 \%$, whereas algal coverage can vary between 0 and $100 \%$. The habitat variables are abbreviated in the following way: rock $(\mathrm{R})$, cobble $(\mathrm{C})$, gravel $(\mathrm{G})$, sand $(\mathrm{S})$, mud $(\mathrm{M})$, macroalgae (MAC) and coralline and turfing algae (CTA). Species names are abbreviated by the first letter of the genus followed by the first letter of the species name. See Table 2 for a list of species names
Fig. 4 shows all 17 species observed in this study in 3D ecological space based on similarity in depth and exposure and the substratum types of the habitat. A 3D MDS solution ( stress $=0.148$ ) was chosen for interpretation as the 2D solution had a stress value of 0.2053 , and stress values above 0.2 are considered to be poor representations of the data (Clarke \& Warwick 2000). Further, the 2D solution was much more difficult to interpret because of the poor representation of distances between species. The inclusion of 4 species (Apopterygion oculus, Bellapiscis lesleyae, Grahamina nigripenne and G. gymnota) with only subset habitat data (see 'Materials and methods') allowed the analysis of all 17 species, though this involved an increase in the stress value from 0.047 to 0.148 . The increase in stress value indicates that the position in ecological space for the 4 subset species is somewhat problematic. This is attributable to a combination of factors, including the relatively low number of observations for A. oculus, B. lesleyae and G. gymnota (33, 37 and 176, respectively). Additionally, all 4 subset species differ considerably in habitat use from the remaining 13 species, as indicated by the difference in the use of depth, exposure (Fig. 2), and substratum type (Fig. 3). The strong habitat differentiation of the 4 subset species can also be seen in the lower mean species comparison DSE-S values for A. oculus $($ mean $=0.6673)$, G. gymnota $($ mean $=0.7396)$ and G. nigripenne $($ mean $=0.6847)$ relative to the mean similarity value of the remaining 13 species (mean $=0.7543$ ). Despite some uncertainty about the position of the 4 subset species in ecological space, the presence of the 4 subset species only slightly affected the relative position of the remaining 13 species, as indicated by a high DSE-S coefficient. The overall wide spread of species in ecological space indicates that triplefins have diversified considerably in habitat use.

The most obvious ecological pattern that emerged was that species that use a similar depth and exposure (Fig. 2) are in close proximity to one another on the MDS plots. This was because triplefin species show greater partitioning in depth and exposure (Fig. 2) than in the use of substratum variables (Fig. 3). Consequently, species with distinctive depth and exposure combinations are separated from all other species in ecological space. Five species were not closely positioned to any of the other species in MDS space (Fig. 4), indicating a high degree of habitat divergence. These species were Apopterygion oculus, Forsterygion flavonigrum, Grahamina capito,
Fig. 4. The 3D MDS solution (stress =0.148) used to represent the DSE-S between 17 triplefin species in multivariate ecological space. Species names are abbreviated by the first letter of the genus followed by the first letter of the species name. See Table 2 for a list of species names 
Table 3. Triplefin microposition use (\%). Abbreviations are explained in Table 1. Micropositions that were used to more than $10 \%$ by a species are highlighted in bold

\begin{tabular}{|lccccccccc|}
\hline Species & STB & UCS & TCO & ALG & UOV & FRE & ROV & SM \\
\hline Apopterygion oculus & 0 & 0 & 0 & 0 & 0 & 0 & 0 & $\mathbf{1 0 0}$ \\
Bellapiscis lesleyae & $\mathbf{9 9}$ & 0 & 0 & 0 & 1 & 0 & 0 & 0 \\
Cryptichthys jojettae & $\mathbf{9 8}$ & 0 & 0 & 0 & 0 & 0 & 2 & 0 \\
Forsterygion flavonigrum & $\mathbf{8 4}$ & 1 & 0 & 7 & 4 & 0 & 0 & 4 \\
Forsterygion lapillum & $\mathbf{7 2}$ & 5 & $\mathbf{1 5}$ & 2 & 0 & 0 & 0 & 7 \\
Forsterygion malcolmi & $\mathbf{9 4}$ & 1 & 0 & 1 & 1 & 0 & 1 & 2 \\
Forsterygion varium & $\mathbf{8 7}$ & 2 & 9 & 0 & 0 & 0 & 0 & 2 \\
Grahamina capito & $\mathbf{6 0}$ & 2 & 1 & 7 & 0 & 0 & 0 & $\mathbf{3 0}$ \\
Grahamina gymnota & $\mathbf{6 7}$ & 9 & $\mathbf{2 4}$ & 0 & 0 & 0 & 0 & 0 \\
Grahamina nigripenne & $\mathbf{6 4}$ & 0 & 0 & 0 & 0 & 0 & 0 & $\mathbf{3 5}$ \\
Karalepis stewarti & $\mathbf{5 9}$ & 0 & 0 & 0 & 0 & 0 & $\mathbf{4 1}$ & 0 \\
Notoclinops caerulepunctus & $\mathbf{3 1}$ & 2 & 0 & 0 & $\mathbf{6 7}$ & 0 & 0 & 0 \\
Notoclinops segmentatus & $\mathbf{9 5}$ & 3 & 0 & 1 & 1 & 0 & 0 & 0 \\
Notoclinops yaldwyni & $\mathbf{9 0}$ & 6 & 0 & 0 & 4 & 0 & 0 & 0 \\
Obliquichthys maryannae & 7 & 3 & 0 & 0 & 0 & $\mathbf{9 0}$ & 0 & 0 \\
Ruanoho decemdigitatus & 5 & $\mathbf{8 9}$ & 3 & 0 & 0 & 0 & 0 & 2 \\
Ruanoho whero & $\mathbf{4 0}$ & $\mathbf{5 0}$ & 4 & 0 & 0 & 0 & 0 & 6 \\
\hline
\end{tabular}

from all other species because, unlike all other species, it was not associated with rocky substratum (Fig. 3). F. flavonigrum was detached in ecological space from the majority of species because it was the only deep water species (Fig. 2) that also occurred sometimes in partly muddy and silty habitats (Fig. 3). G. capito and G. nigripenne were presumably distantly placed to all other species because both species inhabit exclusively shallow, sheltered (Fig. 2) and muddy habitats (Fig. 3). In addition, G. nigripenne differs from G. capito in that it uses rock to lesser degree (Fig. 2). Lastly, Ruanoho decemdigitatus is separated from all other species as it is predominantly found in shallow and sheltered habitats (Fig. 2) characterised by high structural complexity, e.g. boulders and rocks (Fig. 3).

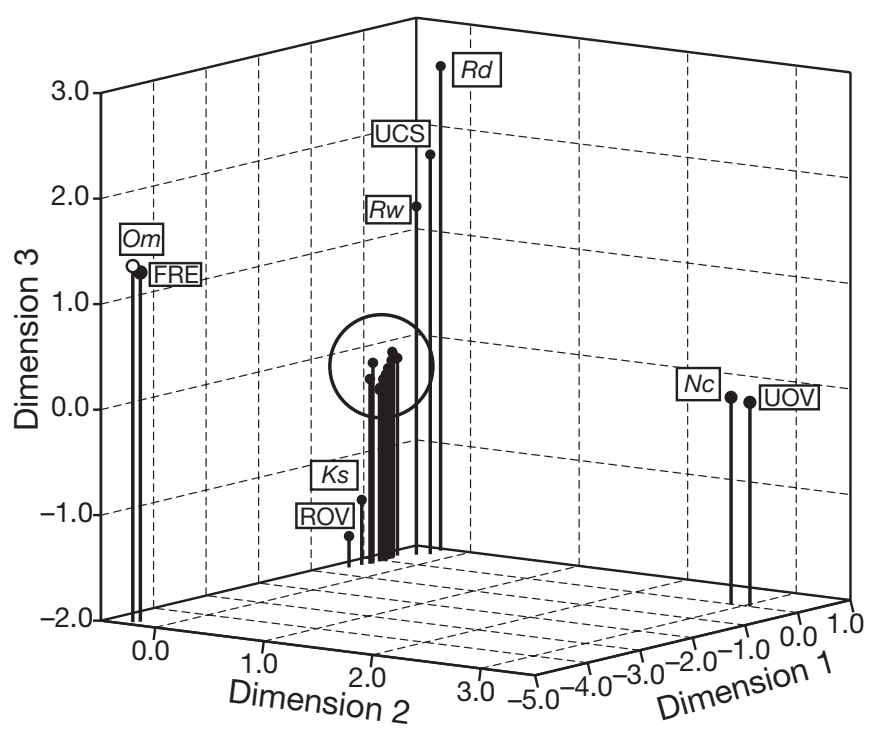

Fig. 5. Use of micropositions by triplefin species. The inertia explained in each of the 3 dimensions is as follows: Dimension $1=39.32 \%$; Dimension $2=19.08 \%$; Dimension $3=17.10 \%$. The cluster (circled) of micropositions and species represents STB, TCO, SM and ALG, A. oculus, B. lesleyae, C. jojettae, F. flavonigrum, F. lapillum, F. malcolmi, F. varium, G. capito, G. gymnota, G. nigripenne, K. stewarti, N. segmentatus and $N$. yaldwyni, which could not be displayed individually due to high overlap. Species names are abbreviated by the first letter of the genus followed by the first letter of the species name. See Table 1 for microposition abbreviations, and Table 2 for a list of species names

G. nigripenne and Ruanoho decemdigitatus. The rotation of $A$. oculus and G. nigripenne was based on habitat subsets, thus cautious interpretation is necessary given that only some habitat variables were considered in the analysis. A. oculus was presumably distantly positioned

\section{Interspecific overlap in microposition use}

Strong overlap in microposition use was apparent between most species, with only 5 species separated out by the Correspondence Analysis (Table 3, Fig. 5). The 3D plot explains $75.5 \%$ of the total variance, which is considered to be a good ordination (Greenacre 1993). These 5 species, namely Notoclinops caerulepunctus, Karalepis stewarti, Obliquichthys maryannae, Ruanoho decemdigitatus, and $R$. whero, were separated from the rest due to their exclusive or predominant use of a few micropositions. In particular, N. caerulepunctus was removed because of its almost exclusive use of the microposition under overhangs (UOV). This microposition was also used, though only to a minor extent, by N. yaldwyni, Forsterygion malcolmi, Bellapiscis lesleyae, $N$. segmentatus and F. flavonigrum (Table 3). K. stewarti was detached in space from all other species due to its use of the microposition 'upside down on roof or overhang' (ROV), a position also used infrequently by Cryptichthys jojettae and F. malcolmi (Table 3). $O$. maryannae was the only species to use the microposition free swimming (FRE), and was thus separated from all other species (Table 3). Lastly, R. decemdigitatus and $R$. whero were separated from all other species because of their use of the microposition under rocks or in cracks (UCS, Table 3 ).

The rest of the species were characterised by the use of several micropositions. The microposition on top or side or rocks (STB) was the most frequently used by all species except Apopterygion oculus, which was exclusively found on a mixture of muddy and sandy substratum types (SM) (Table 3). Grahamina capito and 
G. nigripenne also predominantly occupied muddy and sandy substratum types (SM), however, overlap with other species was high as several other species were also infrequently found in these habitats (Table 3). The position on top of cobbles (TCO) was commonly occupied by Forsterygion lapillum and G. gymnota, and to a lesser extent by Ruanoho decemdigitatus, R. whero, F. varium and G. capito (Table 3).

\section{DISCUSSION}

This study is the first to examine habitat use of New Zealand triplefins over most of their geographic range and in sites other than rocky reefs. In addition, speciesspecific habitat use was not grouped into broad habitat categories, but instead was investigated quantitatively using novel statistical methods. This approach allows interspecific comparisons of species habitat use and thus provides new information about the degree of divergence between species. The results show that New Zealand triplefin species have diversified considerably in habitat use, with species utilizing different patches within the same location. These differences were structured mainly in terms of gradients in depth and exposure, however, some species showed even finer sub-partitioning of substratum types (e.g. rock and mud) and micropositions.

The strong partitioning of habitat by depth and exposure is the most significant component in structuring the New Zealand triplefin assemblage. Studies of other fish assemblages have documented a similar strong role of depth (Bean et al. 2002) and exposure (Thorman 1986, La Mesa \& Vacchi 2005), which together generally comprise the bulk of spatial variation. Factors that may lead to persistent use of habitats within a particular depth and exposure range include species-specific habitat selection at settlement (Leis \& Carson-Ewart 2002), ontogenetic movement (Gibson et al. 2002) or a combination of these factors. In this study, 3 clusters were apparent that classify triplefin species according to their mean habitat depth and exposure. The wide spread of species in these 3 distinct clusters indicates that interspecific divergence in depth and exposure is extensive in this assemblage. This is illustrated by the fact that 2 out of 5 sister species pairs examined are split between different clusters, and that all 3 clusters were made up of species from different genera (for details on phylogenetic relationships see Hickey \& Clements 2005). The mean depth use of the 17 triplefin species ranged from the shallow subtidal (i.e. Bellapiscis lesleyae) to a depth of around $18 \mathrm{~m}$ (i.e. Notoclinops caerulepunctus), and is fairly consistent with previous work on triplefins (e.g. Syms 1995, Feary \& Clements 2006). The only noteworthy exception to this is Apopterygion oculus, which has been recorded from depths in excess of $200 \mathrm{~m}$ (Fricke 1994). However, the use of UVC as a sampling method precludes the census of deepwater habitats $(>40 \mathrm{~m})$, and as a result the mean depth estimates of $A$. oculus are severely biased. Interspecific differences in the exposure of habitats were also extensive, and ranged from sheltered (i.e. Grahamina nigripenne) to highly exposed (i.e. Karalepis stewarti) open water coasts. This is supported by previous work showing that the level of wave exposure affects the composition and the relative densities of this assemblage (Syms \& Jones 1999, Feary $\&$ Clements 2006). However, the exposure measurements of previous studies were based on subjective scales, and thus have to be viewed cautiously.

Substratum use was also highly divergent, even among closely related species such as the Ruanoho sister species pair. Rock appeared to be the most important component of triplefin habitat, as found in previous studies on Forsterygion varium (Connell \& Jones 1991). The only species in which rock did not form the main habitat component was Apopterygion oculus, which is the only triplefin species in New Zealand coastal waters that does not belong to an endemic genus (Fricke 1994). The amount of rock cover was positively correlated with the physical complexity of the habitat (Connell \& Jones 1991), and this is associated with higher abundance in both New Zealand triplefins (Syms 1995) and Mediterranean blennioids (Macpherson 1994). Some authors have suggested that substratum complexity can positively affect fish density through a number of mechanisms, but in particular by increasing shelter opportunities (e.g. La Mesa \& Vacchi 2005). Therefore, it seems likely that the use of rock as a habitat component is related to the degree of protection required by triplefins to shelter from waves and hide from predators. Furthermore, many species exclusively use rock as a nesting substrate during the reproductive season $(\mathrm{M}$. Wellenreuther \& K. D. Clements unpubl.), making the presence of rock in the habitat a necessity during spawning. Cobble and gravel were used to a much lesser extent, indicating that these substratum types are less crucial as a habitat component. Sand and mud, however, were used to a high degree by some species, in particular $A$. oculus, Grahamina nigripenne, and G. capito where the habitat comprised more than $50 \%$ sand and mud. G. nigripenne is the only triplefin species that inhabits estuaries (Clements 2003), thus the high quantity of sand and mud in the habitat of this species appears to be correlated with the estuarine environment. The high amount of sand and mud in the habitat of G. capito is presumably a result of living in shallow and sheltered areas, as the accumulation of sediments is enhanced in these areas (Thorman 1986). 
The broad spread of species in the MDS plot of overall habitat similarity is another indication that wide spread habitat divergence has occurred. Specifically, habitat similarity among closely related species was not particularly strong as there was no close association between sister species pairs and position in multivariate ecological space. For example, although the sister species pair Notoclinops segmentatus and $N$. yaldwyni were closely positioned in ecological space, they were no more ecologically similar than some distantly related species pairs such as Cryptichthys jojettae and N. yaldwyni. Even the Ruanoho sister species pair, which has the least amount of genetic divergence of any species in the New Zealand triplefin assemblage (Hickey \& Clements 2005), showed significant divergence in habitat use, indicating that ecological divergence has occurred at a relatively rapid rate. Thus, the relationship between ecological similarity and phylogenetic relatedness is very weak. It has long been suggested that the strength of ecological interactions among species may be correlated with the degree of evolutionary relationship (e.g. Hutchinson 1965), but in this triplefin system interspecific interactions, such as competition for space, may be as intense between distantly related species as between closely related species. The large MDS distances in ecological space between closely related triplefin species parallels the pattern in Caribbean Anolis lizards, which display a similar tendency for ecological dissimilarity among closely related species (Losos et al. 1998).

Some of the study species were characterised by the use of distinct micropositions, i.e. Obliquichthys maryannae (FRE), Notoclinops caerulepunctus (UOV), Karalepis stewarti (ROV), Ruanoho whero (UCS), and $R$. decemdigitatus (UCS). Unlike the high differentiation in microposition use of the aforementioned species, all remaining species showed high overlap in the use of micropositions. In particular the microposition on the side and top of boulders (STB) was extensively used by the majority of triplefin species, which together with the moderate degree of overlap in other micropositions resulted in a low degree of interspecific differentiation. Syms (1995) found that Forsterygion varium was mainly found on top of cobbles (TCO), whereas in this study it was predominantly observed on the side and top of boulders. Differences in microposition use between the studies may reflect a high degree of intraspecific variation, as this species was generally found to occupy a wide variety of micropositions. In addition, sampling in this study included a wide range of geographically distant locations, therefore differences in microposition use may reflect geographic variation between triplefin populations. Syms (1995) also found that $R$. whero adults commonly occu- pied the microposition on top of cobbles and sometimes the microposition under cobbles, while this study found that $R$. whero adults mainly occupied the horizontal and vertical cracks of rocks (UCS). Syms (1995) also noted that triplefins generally never strayed far from shelter, with the exception of F. varium. Therefore, it seems likely that shelter providing structures, such as rocks, were in the near vicinity of $R$. whero at all times.

The partitioning of microhabitats between ecologically similar reef fish species has been well documented (Bean et al. 2002, Munday 2004), with a large range of fishes either actively selecting specific microhabitats at settlement (Carr 1991) or emigrating into them at juvenile or adult stages (Lewis 1997). Such preferences for distinct microhabitats may represent a survival advantage to fishes, mediating the effects of predation or competition (Forrester \& Steele 2000), providing greater food resources (Clarke 1992) or nesting habitats (Koppel 1988). In this sense, interspecific differences in triplefin microposition use are likely to represent adaptive strategies that allow these fishes to increase their fitness.

In conclusion, this study suggests that New Zealand triplefins have diverged significantly in habitat use, with species occupying different habitat patches in the same general area. It is noteworthy that this pattern was pronounced between closely related species, in particular for the sister species Ruanoho decemdigitatus and $R$. whero. Given that most New Zealand triplefin species occur sympatrically around New Zealand's coastline and that there is no geographic evidence of vicariant barriers (Clements 2003), it is possible that selection on alternative habitats was involved in the diversification of these fishes. Our work thus supports recent studies that invoke a general role of ecology in the diversification and speciation of animals (Rocha et al. 2005, Rundle \& Nosil 2005, Funk et al. 2006).

Acknowledgements. We thank B. Doak and M. Birch for skippering the RV 'Hawere', Z. Hilton and D. Moran for assisting in the field and P. Meredith and S. Wing for the logistical support to do fieldwork in Fiordland. This work was made possible with financial support from a Marsden Fund of the New Zealand Royal Society to K.D.C. (02-UOA-005) and a Top Achiever Doctoral Scholarship from the Tertiary Education Commission (TEC) and a doctoral scholarship from the University of Auckland to M.W.

\section{LITERATURE CITED}

Allender CJ, Seehausen O, Knight ME, Turner GF, Maclean N (2003) Divergent selection during speciation of Lake Malawi cichlid fishes inferred from parallel radiations in nuptial colouration. Proc Natl Acad Sci USA 100: 14074-14079 
Andrew NL, Mapstone BD (1987) Sampling and the description of spatial pattern in marine ecology. Oceanogr Mar Biol 25: 39-90

Barrett PT (2005a) Euclidean Distance: raw, normalised, and double-scaled coefficients. Available at www.pbmetrix.com

Barrett PT (2005b) Agreement Matrix Constructor. Available at www.pbmetrix.com

Barrett PT (2005c) ORTHOSIM2 - Factor and multidimensional scaling orthogonal vector matrix comparison. Available at www.pbmetrix.com

Bay LK, Jones GP, McCormick MI (2001) Habitat selection and aggression as determinants of spatial segregation among damselfish on a coral reef. Coral Reefs 20: 289-298

Bean K, Jones GP, Caley JM (2002) Relationships among distribution, abundance and microhabitat specialisation in a guild of coral reef triggerfish (family Balistidae). Mar Ecol Prog Ser 233:263-272

Bouchon-Navaro Y, Bouchon C, Louis M, Legendre P (2005) Biogeographic patterns of coastal fish assemblages in the West Indies. J Exp Mar Biol Ecol 315:31-47

Brook FJ (2003) Three Kings Islands. In: Andrew N, Francis M (eds) The living reef. The ecology of New Zealand's rocky reefs, 1st edn. Craig Potton Publishing, Nelson, p 202-209

Carr MH (1991) Habitat selection and recruitment of an assemblage of temperate zone reef fishes. J Exp Mar Biol Ecol 146:113-137

Chiswell SM (2002) Wairarapa coastal current influence on sea surface temperature in Hawke Bay, New Zealand. N Z J Mar Freshw Res 36:267-279

Clarke KR, Warwick RM (2000) Change in marine communities: an approach to statistical analysis and interpretation, 2nd edn. Plymouth Marine Laboratory, Plymouth

Clarke RD (1992) Effects of microhabitat and metabolic rate on food intake, growth and fecundity of two competing coral reef fishes. Coral Reefs 11:199-205

Clements KD (2003) Triplefins. In: Andrew N, Francis M (eds) The living reef. The ecology of New Zealand's rocky reefs, 1st edn. Craig Potton Publishing, Nelson, p 160-167

Connell SD, Jones GP (1991) The influence of habitat complexity on postrecruitment processes in a temperate reef fish population. J Exp Mar Biol Ecol 151:271-294

Feary D (2001) Trophic morphology, diet and habitat use of New Zealand triplefins (Family Tripterygiidae). MSc thesis, University of Auckland

Feary DA, Clements KD (2006) Habitat use by triplefin fishes (family Tripterygiidae) on rocky reefs in New Zealand. J Fish Biol 69:1031-1046

Fisher CJ (1998) Population ecology of three species of triplefins (family Tripterygiidae). MSc thesis, University of Auckland, New Zealand

Forrester GE, Steele MA (2000) Variation in the presence and cause of density-dependent mortality in three species of reef fishes. Ecology 81:2416-2427

Francis MP (1996) Geographic distribution of marine reef fishes in the New Zealand region. N Z J Mar Freshw Res 30:30-55

Francis MP (2001) Coastal fishes of New Zealand. An identification guide, 3rd edn. Reed Books, Auckland

Fricke R (1994) Tripterygiid fishes of Australia, New Zealand and the Southwest Pacific Ocean (Teleostei). Koeltz Scientific Books, Königstein

Funk DJ, Nosil P, Etges WJ (2006) Ecological divergence exhibits consistently positive associations with reproductive isolation across disparate taxa. Proc Natl Acad Sci USA 103: 3209-3213

Gibson RN, Robb L, Wennhage H, Burrows MT (2002) Ontogenetic changes in depth distribution of juvenile flatfishes in relation to predation risk and temperature on a shallowwater nursery ground. Mar Ecol Prog Ser 229:233-244

Greenacre MJ (1993) Correspondence analysis in practice. Academic Press, London

Gust N, Choat HJ, McCormick MI (2001) Spatial variability in reef fish distribution, abundance, size and biomass: a multi-scale analysis. Mar Ecol Prog Ser 214:237-251

Heath RA (1985) A review of the physical oceanography of the seas around New Zealand. N Z J Mar Freshw Res 19: 79-124

Hickey AJR, Clements KD (2005) Genome size evolution in New Zealand triplefin fishes. J Hered 7:356-362

Hutchinson GE (1965) The ecological theater and the evolutionary play. Yale University Press, New Haven, CT

Koppel VH (1988) Habitat selection and space partitioning among two Mediterranean blennioid species. PSZN I: Mar Ecol 9:329-346

La Mesa G, Vacchi M (2005) Analysis of the blennioid assemblages associated with different rocky shore habitats in the Ligurian Sea. J Fish Biol 66:1300-1327

Leis JM, Carson-Ewart BM (2002) In situ settlement behaviour of damselfish (Pomacentridae) larvae. J Fish Biol 61: 325-346

Lewis AR (1997) Recruitment and post-recruit immigration affect the local population size of coral reef fishes. Coral Reefs 16:139-149

Losos JB, Jackmann TR, Larson A, Queiroz KD, SchettinoRodriguez L (1998) Contingency and determinism in replicated adaptive radiations of island lizards. Science 279: 2115-2117

Lu G, Bernatchez L (1999) Correlated trophic specialisation and genetic divergence in sympatric lake whitefish ecotypes (Coregonus clupeaformis): support for the ecological speciation hypothesis. Evolution 53:1491-1505

Macpherson E (1994) Substrate utilisation in a Mediterranean littoral fish community. Mar Ecol Prog Ser 114:211-218

Malavasi S, Franco A, Fiorin R, Franzoi P, Torricelli P, Mainardi D (2005) The shallow water gobiid assemblage of the Venice Lagoon: abundance, seasonal variation and habitat partitioning. J Evol Biol 67:146-165

Munday PL (2004) Competitive coexistence of coral dwelling fishes: the lottery hypothesis revisited. Ecology 85:623-628

Munday PL, Jones GP, Caley MJ (1997) Habitat specialisation and the distribution and abundance of coral-dwelling gobies. Mar Ecol Prog Ser 152:227-239

Nemeth RS (1998) The effect of natural variation in substrate architecture on the survival of juvenile bicolor damselfish. Environ Biol Fishes 53:129-141

Ormond RFG, Roberts JM, Jan RQ (1996) Behavioural differences in microhabitat use by damselfishes (Pomacentridae): implications for reef fish biodiversity. J Exp Mar Biol Ecol 202:85-95

Paulin CD, Roberts CD (1992) The rockpool fishes of New Zealand. Museum of New Zealand, Te Papa, Tongarewa, Wellington

Rocha LA, Robertson DR, Roman J, Bowen BW (2005) Ecological speciation in tropical reef fishes. Proc R Soc Biol Sci Ser B 272:573-579

Rundle HD, Nosil P (2005) Ecological speciation. Ecol Lett 8: 336-352

Schofield PJ (2003) Habitat selection of two gobies (Microgobius gulosus, Gobiosoma robustum): influence of structural complexity, competitive interactions, and presence of a predator. J Exp Mar Biol Ecol 288:125-137

Seehausen O, Van Alphen JJM, Witte F (1997) Cichlid fish diversity threatened by eutrophication that curbs sexual selection. Science 277:1808-1811 
Syms C (1995) Multi-scale analysis of habitat association in a guild of blennioid fishes. Mar Ecol Prog Ser 125:31-43

Syms C, Jones GP (1999) Scale of disturbance and the structure of a temperate fish guild. Ecology 80:921-940

Thomas MLH (1986) A physically derived exposure index for marine shorelines. Ophelia 25:1-13

Thompson S (1983) Homing in a territorial reef fish. Copeia 3: 832-834

Thorman S (1986) Physical factors affecting the abundance and species richness of fishes in the shallow waters of the

Editorial responsibility: Howard Browman (Associate Editorin-Chief), Storebø, Norway southern Bothnian Sea, Sweden. Estuar Coast Shelf Sci 22: $357-370$

Willis T (2001) Visual census methods underestimating density and diversity of cryptic reef fishes. J Fish Biol 59:1408-1411

Wilson S (2001) Multiscale habitat associations of detrivorous blennies (Blenniidae: Salariini). Coral Reefs 20:245-251

Wing S (2003) Fiordland. In: Andrew N, Francis M (eds) The living reef. The ecology of New Zealand's rocky reefs, 1st edn. Craig Potton Publishing, Nelson, p 238-247

Submitted: April 7, 2006; Accepted: June 6, 2006

Proofs received from author(s): January 9, 2007 